\title{
5. White Hair and Feeding Bottles: Exploring Interactions Between Children and the Elderly in the Late Bronze Age Aegean
}

\author{
CHRYSANTHI GALLOU
}

Gallou, C. 2018. Across the Generations: The Old and the Young in Past Societies. AmS-Skrifter 26, 61-75, Stavanger. ISSN 0800-0816, ISBN 978-82-7760-181-6.

Scholarship on age and gender in prehistoric Greece has taken an adult-centric approach with focus placed mostly on young to middle-aged men and women and, as a result, two significant age groups - children and the elderly - have been widely neglected. Lacking a strong insight into attitudes that were shown towards these two age groups, however means that archaeologists do not really harbour a concept of the whole span of life in the cultures that developed in the Aegean region during the Late Bronze Age. Making children and the elderly visible in the archaeological record and examining their social roles, agency and interactions is vital for a better understanding of the social workings of the prehistoric Aegean world. Integrating an interdisciplinary methodology with a systematic study of the available material remains - ranging from the study of funerary contexts to iconographic sources and textual references, this study seeks to assess the evidence for childhood and old age in the Late Bronze Age Aegean, and to shed light - for the first time - on the interactions between the younger and older segments of the population in both life and death from the mid-seventeenth to the twelfth centuries BC.

Keywords: Childhood; old age; Aegean; socialisation; alloparenting; apprenticeship

Address: Department of Classics and Archaeology, University of Nottingham, University Park, Nottingham NG7 2RD, UK. Email: Chrysanthi.Gallou@nottingham.ac.uk

\section{Introduction}

Whereas a remarkable amount of research has been undertaken on the perception of gender in the prehistoric Aegean since, at least the early 1990s, ${ }^{1}$ little work has focused on the social meanings attached to childhood and old age by the Aegean societies of the second millennium $\mathrm{BC}$, or on the contribution of these two age grades to the formation of social and cultural identities in the region. This attitude appears to be universal in archaeology, partly stemming from the low social and economic value often placed upon the earlier and the later part of the life-span in present-day societies (Appleby 2011).

Children and the elderly are generally underrepresented in the archaeological record of the Late Bronze Age Aegean as a result of collective burial, the reuse of tombs and the performance of post-funerary rites which encouraged ritual interference with, and re-arrangement of, the skeletal remains (sometimes unintentionally causing damage, especially to fragile immature skeletons) and of the burial offerings (which may be used as indicators of gender and age, though not always without caution), thus obscuring the secure identification of child and elderly burials (Gallou 2004; in press; Gallou-Minopetrou 2015, 57). ${ }^{2}$ Equally dissuasive in attempting to identify children and the elderly in the prehistoric Aegean is the relative 'unwillingness' of the prehistoric artist to portray figures other than men and women in the prime of their life with standardised physical attributes, regardless of their chronological age or physical appearance. Scholars have started to identify 'marginalised' groups in prehistoric Aegean iconography, however, including children of various age grades (from infancy to adolescence) and, less frequently, elderly individuals.

No doubt, though, with this lack of a strong insight into the attitudes that were shown towards these two age groups, archaeologists cannot really harbour a concept of the whole span of life in the cultures that developed in the Aegean region during the Late Bronze Age. 
Making children and the elderly visible in the archaeological record and examining their social roles, agency and interactions is vital for a better understanding of the social workings of the prehistoric Aegean world. In this line of enquiry and by integrating ethnographic parallels with a systematic study of the available material remains - ranging from funerary contexts to iconographic sources and textual references, this study assesses the evidence for childhood and old age in the Late Bronze Age Aegean and, for the first time, sheds light on the interaction between youths and the elderly in both life and death in the second millennium BC, with a focus on Minoan and Mycenaean societies.

\section{In Search of the Prehistoric Aegean Child}

While the study of childhood has become a particularly influential area of archaeological enquiry, especially since Grete Lillehammer's seminal paper A Child is Born (1989), and despite the advances in establishing an international academic discourse on the subject over the last twenty-five years (Baxter et al. 2017; Crawford 2017; Lillehammer 2015), the cultural study of children and childhood has only quite recently started to gain significant ground in Aegean archaeology (for a full bibliography on relevant studies see Gallou 2004; 2010; in press; Gallou-Minopetrou 2015). It is also in recent years that the study of Aegean children in biological anthropology has been providing more focused information on important aspects such as growth, development, health and disease and mortality patterns (Bourbou 2013, 332. Also, IngvarssonSundström 2008 and Triantaphyllou 2016, 161). Bearing in mind that 'one of the resounding issues with the definition of a "child" in archaeological contexts is the use of physiological age to determine social category' (Lewis 2007, 5), childhood is as much a biological stage of human development as a social construct that emerges from the attitudes, beliefs, expectations and values of adult societies at particular points in time (Ingvarsson-Sundström 2008, 20-1). For the purposes of this study, the age limits for the Late Bronze Age 'child' are very broadly defined as - neonate and infant (birth to 3 years), child (3-12 years) and adolescent (1216 years). It should be noted, though, that a clear, fixed categorisation of sub-adult age groups is still lacking in Aegean archaeology.

Evidence for Late Bronze Age Aegean children comes from burial contexts, pictorial art (figurines, frescoes, pottery and terracottas, seals and jewellery), artefacts traditionally, though not exclusively, associated with childhood (figurines, feeding bottles and miniatures), and palm prints and fingerprints on Linear B clay tablets (see e.g. Polychronakou-Sgouritsa 1987; Gates 1992; Rutter 2003; 2007; Gallou 2004; 2010; in press; Chapin 2007; Rehak 2007; Papageorgiou 2008; Younger 2009; Budin 2011, 269-325; 2014; Pomadère 2012; Günkel-Maschek 2014; Gallou-Minopetrou 2015). In order to identify children in Late Bronze Age Aegean art the following criteria have been established (Rehak 2007, 206-7), although some deviation from these may be occasionally noticed:

a) In pictorial scenes where more than one individual is depicted, girls are usually recognised as the relatively smaller females.

b) Girls wear a calf-length version of the ankle-length robe with short sleeves worn by adult women; in a sense, girls are represented as miniature adults. On the other hand, boys are always nude.

c) The developmental stages of the face and the body can be estimated as young individuals growing toward maturity, and both boys and girls went through several stages of hair growth and cutting before maturity ( $c f$. Davis 1986; Chapin 2002; 2007; 2009; Lebegyev 2009; Günkel-Maschek 2014, fig. 6).

Images of mothers with children are almost entirely absent in Minoan Crete (Budin 2011, 284; 2016) and children appear to have been recognised in various stages of life as either individuals or members of peer groups rather than as components of nuclear families which, according to Rutter $(2003,49)$, may underline a more independent role in their communities. On the other hand, children on the Mycenaean mainland were perceived as components of a nuclear (if not extended) family since they are often accompanied by one or more adults when they are represented in pictorial art. They are also recorded in approximately 200 Linear $B$ administrative documents of the personnel series from the administrative centres at Pylos and Knossos as components of units, recipients of rations and as assistants in the workshops of specialised female adult workers (Olsen 1998; Nosch 2001; Gallou 2010). They are differentiated by sex (both at Pylos and Knossos) but only at Knossos by age grades under the epithets $m e-z o$ (=older) and me-wi-jo, me-u-jo (=younger); it is not certain, though, what these epithets might have signified for the Mycenaeans. Childcare was possibly assigned to Mycenaean women and, when older boys are listed accompanying men, this was probably for the purposes of professional instruction (Olsen 1998, 384; 
Nixon 1999. Note, though, the reservations expressed in Budin 2014, 109).

\section{An Archaeological 'Silver Alert'}

Up until recently old age has rarely been a focus of archaeological studies and is usually discussed rather vaguely (Appleby 2010, 148ff; 2011, 231). Although the topic has been addressed in the study of classical Greece since the 1930s (e.g. Kirk 1973; Garland 1990, 242-87), there has, as yet, been no holistic and comprehensive discussion of old age in Aegean prehistory.

By and large there are some considerable shortcomings associated with the study of old age in archaeology. First, the dearth of appropriate and testable methods for identifying the aged in cemetery samples has stalled research in this area and as a result the bioarchaeology of the elderly ranks amongst the least explored sub-disciplines of biological anthropology and mortuary archaeology (see Maaranen and Buckberry, this volume; Cave and Oxenham 2014, 17). As a result, a conservative approach is usually adopted that assigns only broad age groups to adult skeletons, with a final open-ended age group of 50+ years ( $c f$. Agarwal 2012, 330; Cave and Oxenham 2014). No bioarchaeological study has yet attempted to comprehensively assess senescence or to investigate finer age cohorts among the mature-elderly lifespan for the prehistoric Aegean, and old age is usually estimated from around 50+ years of age and over (Lagia et al. 2007, 316; Triantaphyllou 2010, 448; 2016, 161ff.). In their examination of the Middle Bronze Age skeletons from Kouphovouno, however, Lagia and colleagues $(2007,324)$ correctly proposed that some of the middle adults (35-49 years) examined should also enter the old age category to provide a more realistic profile in demographic terms. The boundaries of senescence (as of childhood) can therefore be fluid and, as recent scholarship has shown, chronological age on its own is not the primary determinant of age identity in many non-literate societies (Welinder 2001, 163, 165; Appleby 2010, 150):

Like no other, the historical perspective illustrates that age is not an anthropological, biological or calendar constant. (Old) Age is a socio-cultural construct that is shaped in the respective society, emerges historically and changes historically. This issue concerns the numerical proportion of the elderly in the total population, their living conditions, and finally the answer to the question of who is considered old at all. Age was and is also characterised by gender, status and stratum specific and not least individual characteristics in the respective time (author's translation of the original text in Luh 2003, 315). ${ }^{3}$

This may well be the case of the Mycenaean ke-rosi-ja (geronsia, gerousia) mentioned in administrative Linear B tablets (PY An261, PY An616) in the palatial archives of Pylos (Ventris and Chadwick 1973, 172, 421). The term has been taken to either signify a local administrative Council of Elders presided over by a qa-si-re- $u_{2}$ ( $g a^{u}$ sileus, local chief) (Shelmerdine 2008; Palaima 2014, 87) or a corporation of highly specialised and highly experienced craftsmen which 'outsiders', such as an individual from Kythera, were also able to join (Efkleidou 2002-3, 278). Both interpretations are probably correct and interconnected since in many traditional societies individuals of advanced age are/ were often considered to be the personalisation of wisdom and the keepers of craft knowledge (see e.g. Garland 1990, 266). Therefore, the Mycenaean palatial elites might have considered it appropriate to appoint a council consisting of elderly and highly specialised craftsmen to locally oversee palatial production under the auspices of the qa-si-re- $u_{2}$.

Furthermore, Aegean iconography appears to be relatively mute when it comes to the depiction of elders; even when they are shown, there is no way to tell how old those people might have been perceived to be by the artist. The earliest portrayals of elderly individuals may date to the Neolithic and they are recognised 'by their fleshy but not so firm bodies and faces sometimes marked by signs of advanced age' (Hitchcock and Nikolaidou 2013, 505 citing Chourmouziadis 1994). Sir Arthur Evans identified elderly men in Minoan iconography by the looser belts they wore as, for example, the 'old sistrum-player' on the so-called 'Harvester Vase' from the Villa at Aghia Triadha and the bronze male figurine from Tylissos House A, both dating to c. 1550-1500 BC (Evans 1930, 449-50, fig. 313; Rehak 2009, 15, pl. IIe). The seated mature man with a slight paunch (characteristic of older age), clad in a white zoma (loincloth) from near the Lustral Basin in Xeste 3 on Thera (Rehak 2002, 43, fig. 2.5) should also be considered to represent an individual of old age. Of senior age also appears to be the man who leads the march on the 'Harvester Vase' (Forsdyke 1954, pl. 2a); he features nape-length hair and a properly groomed beard, is dressed in a robe or cloak decorated with a scale pattern and with a tasselled fringe at the bottom, and carries a staff. All of these characteristics are often identified as insignia of official status and senescence in Minoan culture (Marinatos 2010, 21-3). In appearance the figure resembles the older bearded 'priests' 
apparent on a number of Minoan seals (Rehak 1998, 194; German 2000, 98, 102; Crowley 2013, 146 \#E34, 195 \#E131a; Betts 2015), the male portraits carved on the minuscule amethyst disc-shaped seal from Shaft Grave Gamma in Grave Circle B at Mycenae (Mylonas 1983, fig. 40) and the older males in long robes in Mycenaean pictorial art (German 2000, 101; Crowley 2013, 191 \#E123).

Women of older age are sometimes portrayed in Aegean art and they are often distinguished by their bulky bodies, thick waists, enormous sagging breasts, back hump, double chins, absence of colour or outline for denoting the lips, bloodshot eyes (as opposed to the blue-streaked corneas of the young girls in Xeste 3: Davis 1986, 401-4) ${ }^{4}$ and/or hair bound in snoods like the Classical sakkos (Doumas 1992, 131; Morgan 2000, 938-9; Gallou-Minopetrou 2015, 62, fig. 2). Thus, although previously the 'Five Mature Ladies' from the fresco on the upper floor hallway (Room 3b, upper level) of Xeste 3 at Akrotiri, Thera (Doumas 1992, pls. 131-4), were interpreted as fertile women (Chapin 2002, 25), their bulky bodies, thick waists, large and heavy breasts, eyes with red streaks and hair bound in snoods like the Classical sakkos suggests they must be old by Minoan standards (Younger 2016a, 586) and past menopause and childbearing (Younger 2009, 210). Of advanced age, even older than the ladies from Xeste 3, appear to be Ladies A and B on the cult scene from the 'House of the Ladies' (Marinatos 1984, 97-105, figs 67-8; Davis 1986, 404; Younger 2016a, 574).

Finally, a glimpse into the whereabouts of some Mycenaean elderly women may be gained through their mention as ka-ra-we (grāwes, old women) in the palatial textile personnel lists from Knossos (KN Ap694; KN Ap5868+8220) (Nosch 2003, 17; Olsen 2014, 38-9, 177). In classical antiquity the term graia had a somewhat pejorative connotation and was probably applied to women past menopause (Garland 1990, 243). It is less certain though that the term ke-ro-te (gerontes) denoted 'old men' in the (erased) mention on tablet KN B800 (Ventris and Chadwick 1973, 122, 553).

\section{Intergenerational Relations in the Prehistoric Aegean: Children and Elders in Interaction}

Although there are no direct references, either literary or iconographical, showcasing the dealings of children and the elderly in the Late Bronze Age Aegean, indirect archaeological evidence and ethnographic correlations allow an effective reconstruction of possible patterns of interaction between the two age groups in both life (i.e. alloparenting and later-life support traditions, apprenticeship and socialisation, healing) and death.

\section{Big Caring Families}

In many cultures grandparenting is 'a core component of family support in the broader context of intergenerational exchanges, constituting an important emotional and economic resource for parents and children alike' (Hank and Buber 2009, 55). In traditional societies when mothers' energies are to be devoted to subsistence or commercial activity and to preparing themselves for the next birth, they usually pass off their infants and toddlers to siblings or granny caretakers (Lancy 2015, 141-4, 403; Valentine et al. 2016, 494). This practice seems to have deep evolutionary roots (Hawkes et al. 2000; Hrdy 2009). In modern Greece over a third (38\%) of grandparents provide daily child care and other kinds of family help, including financial assistance to the parental generation (Svensson-Dianellou et al. 2010). Alloparenting may often extend to the larger kinship (uncles/aunts, cousins, co-parents-in-law) or local community networks (Georgas et al. 2001) for example, up until the 1980s the elderly women at Agios Nikolaos Voion in southern Lakonia would mind weaned children, while the biological mothers were undertaking agricultural tasks away from home (Sarantos Minopetros, pers. comm.). Alloparenting was not uncommon in classical antiquity either; instructive are the Attic grave-relief commemorating Ampharete and her grandchild (c. $410 \mathrm{BC}$ ), ${ }^{5}$ the fourth-century $\mathrm{BC}$ Attic figurines showcasing standing or seated old nurses with babies, and the fifth-century Tanagra terracotta figurine depicting a seated old man offering grapes to a young girl (Neils and Oakley 2003, 3, 184, 227-8, 233).

Unfortunately, direct testimonies for Mycenaean alloparenting are lacking but there are hints in the archaeological record, namely kourotrophic imagery, which could testify to such practice. ${ }^{6}$ Although kourotrophism seems to have been largely absent from Minoan Crete, the Mycenaeans celebrated it in the form of terracotta figurines depicting a female figure - standing or seated - nursing a child from c. 1450 BC onwards (Budin 2011, 283, 300-14; Olsen 1998) (Fig. 1). Olsen has argued that Mycenaean kourotrophic iconography was the result of the contemporary gender constructs which placed women firmly within the domestic sphere as child-rearers: 'It may not be motherhood per se that is being celebrated in Mycenaean 
society but rather the locating of women in domestic contexts which is iconographically reinforced' (Olsen 1998, 390. Note, though, Budin 2014, 109; 2016). Maternity and childcare are mostly absent from the palatial administrative records where women and children are merely mentioned as members of the labour force. Although, kourotrophic figurines are often interpreted as mother-child depictions, no alternative mention has been made to the possible imagery of alloparenting, especially when considering that a great number of mothers would have been engaged in the palatial textile industry or other labour activities away from home (for Mycenaean women at work, see Budin 2016, 601ff; Shelmerdine 2016). As a matter of fact, there are only very few Linear B administrative texts (e.g. MY V659, Oe 106 and Oe112 and possibly the Knossos Ap series) that appear to specifically mention mothers with their daughters ( $t u-k a-t e)$ and in two cases with an infant girl (ki-ra) each in a palatial textile workgroup context as in tablet MY V659 which reads (Budin 2016, 602-3):

Wordieia de-mi-ni-ja
Ma-no and Alexandra
ri-su-ra and qo-ta
e-ri-tu-pi-na and Theodora
Orthowowije and daughter
Anea and daughter
Philowoina and little girl
Pu-ka-to and ke-ti-de
...
Keraso and little girl

The adult female - young girl pairs have been interpreted as specifying the Mycenaean mother - daughter relationship (Budin 2011, 319), with tu-ka-te (daughter) possibly designating an age class of young workers of hereditary title who were about to enter the adult world after being trained in the profession alongside their mothers since childhood (Carlier 1999, 187-8). Of interest is the mention ki-ra used to describe a 'little girl', perhaps even an infant, according to Duhoux (2008, 292-3). However, considering that Linear B texts were of strictly administrative character, why would the two infant girls be of any concern to the palatial bureaucrats? Given their very young age (perhaps unweaned, if the term ki-ra did not correspond to the Knossian $m e-w i-j o, m e-u$-jo age grade), it is unlikely they were expected to enter training in the palatial textile industry, especially since the specific tablet records the allotment of wool to the female workgroup. If Philowoina and Keraso are indeed biological mothers recorded with their infants for some specific reason, albeit unknown

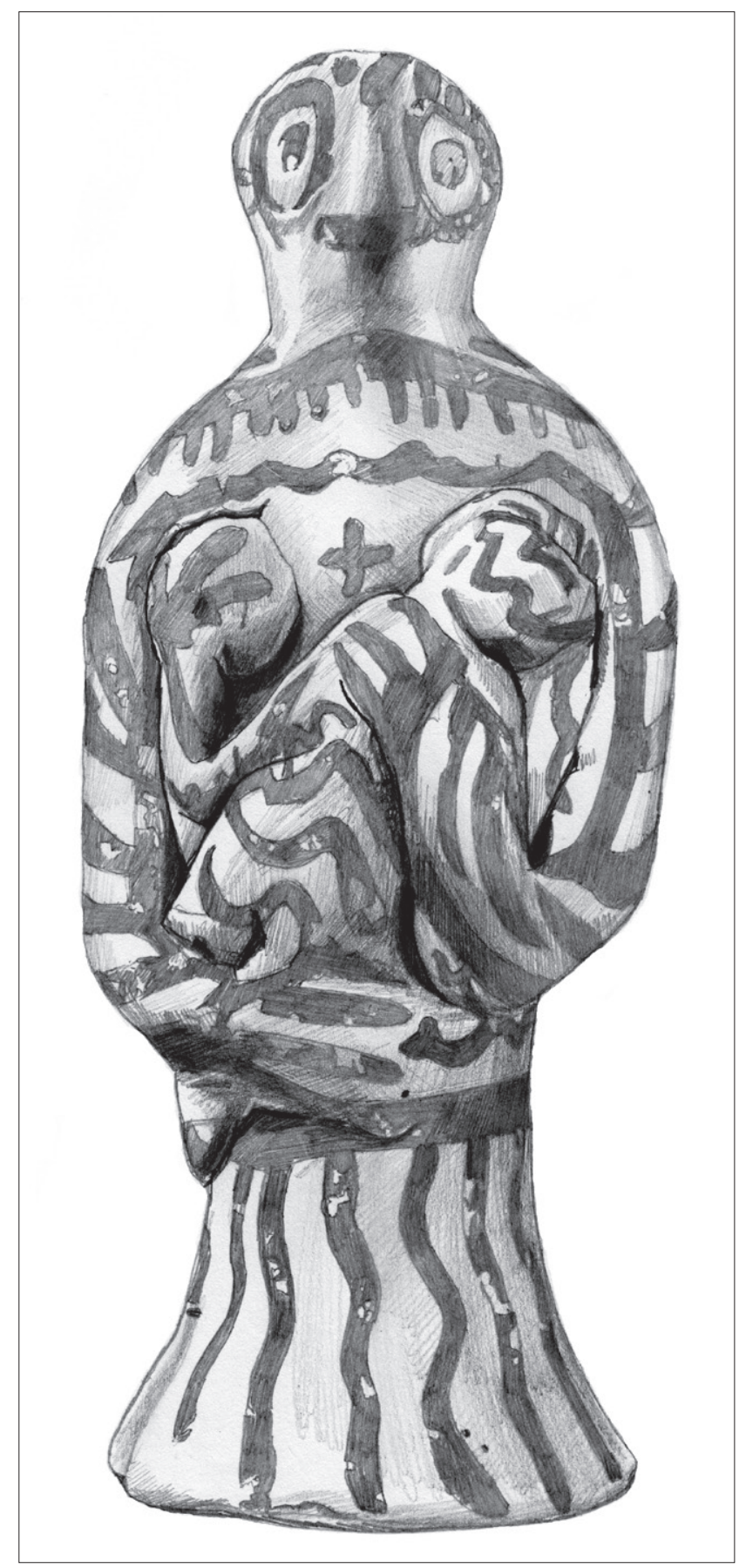

Figure 1: Mycenaean Phi kourotrophos from the cemetery at Aidonia, drawn by Paul Butler (Budin 2011, fig. 44).

to us, then why are there not more such records of infants? Could the two adult women be identified instead as the grandmothers of the two girls? Reports for traditional societies such as the Chiga of western Uganda show that it is not uncommon for grandmothers to intervene at critical times, particularly during weaning (Lancy 2015, 142-3). May it be possible then, based on ethnographic parallels, to suggest that Mycenaean childcare for unweaned infants, or children too young to work, might have been assigned to grannies 
for facilitating participation of the biological mothers in the labour force and shaping the work-family nexus? Another explanation that may merit further examination is the possibility of these girls not being relatives of the above women, but rather children (maybe orphans or foster children?) under their protection.

Another type of interaction might have been later-life support within the Aegean household. As grandparents could have taken care of the younger members of the family, likewise children of older age might have cared for the infirm elders of the household at times when the fit adult members of the family would have been engaged in other activities away from home. Although there is no direct evidence from the Late Bronze Age Aegean record for such interaction, it is not unlikely that family dwellings may have housed extended families (e.g. the Panagia Houses at Mycenae; Mylonas Shear 1987) and that support for elderly family members may have been practised similarly to the ancient (Garland 1990, 261-2) and modern Greek traditions of later-life support within the family (Mpalogiannis 2007).

\section{For the Sake of Learning:}

\section{Socialisation and Apprenticeship}

'For the sake of learning, children engender and develop skills at the hands of the adults that linger in the background' (Lillehammer 2010, 17) and this could also be argued for prehistoric Aegean socialisation and apprenticeship pedagogy. A sense of peer loyalty might have been cultivated in the second millennium BC Aegean culture with male youths placed under the tutelage of older men as suggested by the older man younger boy juxtaposition on Minoan seals (Marinatos 2005, 158, fig. 9.16; Crowley 2013, 77 \#I30a, 187 \#E115). Tutelage becomes more apparent in the context of cult and ritual, as clearly reflected by the mid-seventeenth century $\mathrm{BC}$ decorative programme of Xeste 3 , a threestorey edifice with impressive façades, large halls with polythyra, a grand staircase and a service one in the interior, stone benches and a Lustral Basin at Akrotiri, Thera ( $c f$. Doumas 1992, 127-31; Vlachopoulos 2008, 491). The surviving wall paintings vividly illustrate the gathering of crocus blossoms in a mountainous setting and the adoration of a female deity, a Potnia Theron (or Mistress of Animals), who is resting on a multi-coloured elevated tripartite platform flanked by a leashed griffin, a procession of five matronly women, three females engaged in ritual activity near an architectural structure dripping blood and, in a separate area, male figures engaged in a ritual. Based on its architectural layout and iconographical programme,
Xeste 3 has been identified as a public building that served actual gender-separation ceremonies or rites on both the ground and the first floors (Vlachopoulos 2016, 380). Pertinent to male youth - old man tutelage are the wall paintings in Room 3b which depict three young individuals - one child and two adolescents converging towards a seated mature man with a slight paunch, clad in a white zoma (Vlachopoulos 2008, 492, pl. 41.51). This scene has been interpreted as a manhood initiation rite for one of the adolescent males led by the older man (Marinatos 2005, 158).

The murals on the upper storey focus on the depiction of female figures of various ages - from prepubescence to old age as suggested by the different stages of hair growth and hairstyles, variations in the garments and jewellery and by the careful rendering of physiological attributes such as eyes and breast development. These scenes have received various but inconclusive interpretations: from representing puberty rites, initiation and engendering processes, marriage, fertility rituals, autumnal rebirth and mythological narrative, to local female-focused industry/economic activity or healing (e.g. Marinatos 1984; 2016; Davis 1986; Morgan 1990; 2005; Doumas 1992, 128, 130; 2000; Chapin 2002; Gessell 2000; Porter 2000; Sarpaki 2000; Koehl 2001; Rehak 2002; Vlachopoulos 2003; 2007; 2008, 493; 2010; 2016; Ferrence and Bendersky 2004; Younger 2009, 211; Günkel-Maschek 2014; Jones 2016, footnote 1).

Of particular relevance to female youth - elderly woman tutelage is the illustration of the 'Five Mature Ladies' in procession along the upper floor hallway (Room 3b) (Doumas 1992, 169, pls. 131-4; Rehak 2002, 36; Shank 2012; Vlachopoulos and Zorzos 2014, 193; Younger 2009, 210). The women are fully clad in typical Minoan attire but with the addition of a thick, fleecy mantle - dyed either red or saffron yellow - which features puffy, irregular edges and wavy internal lines, attached at one shoulder. The diaphanous saffron yellow blouse, the headdress and the cheek of the woman with the wicker basket, were decorated with (now faded) purple crocus stigmas (Rehak 2004, 91). The 'Rose Bearer' wears a diaphanous blouse, with painted or embroidered red lilies, and carries a bunch of wild roses; her mantle was dyed in saffron yellow. The snood of the lesser preserved figure of the fifth mature woman on the eastern wall of the corridor was adorned with a fruited olive branch and a wild rose; she seems to be handling a stone vase and perhaps a rhyton (ritual vessel used for libations), probably as part of an activity that involved liquids (Vlachopoulos 2003, 521, n. 22; 2008, 453-4; Günkel-Maschek 2012, 363-4). Considering 
their advanced age, costumes rich in floral iconography and their participation in a ritual activity or ceremony involving plants and liquids, the women present a close connection with (or at least part of) the ritual activities depicted in the mural decoration of the upper floor. The scene possibly also replicates actual rites and related activities that were taking place in the building and probably in other buildings around Akrotiri. Based on their special ceremonial attire and the ritual storyline of the scene, these mature women may be interpreted as distinguished members of the local elite and as priestesses in the service of the Potnia (Rehak 2007; Vlachopoulos 2008, 493; Murray 2016, 70). Part of their priestly duties would have included tutelage of young female acolytes in the labour-intensive task of crocus gathering in dangerous rocky locales, and subsequently into priesthood (Rehak 2007). This is self-explanatory through the iconographical agenda: the wicker basket carried by one of the matrons resembles the containers used by the girl attendants who gather crocus blossoms for the goddess. This may also suggest the matron might have been a flower-picker in her youth (Rehak 2004, 93).

Moving on to other examples of interaction, the Mycenaean palatial textile records document children of both sexes and various age grades working under instruction in the textile industry alongside adult women, possibly their mothers (see Gallou 2010). Elderly women (ka-ra-we) are occasionally recorded with these mixed-age workgroups and may have acted as instructors (Nosch 2003, 170). It may thus be plausible to assume that apprenticeship in a palatial textile industry context might have been another form of interaction between the elderly and the children.

Inside the household, grandfathers would have been a great source of knowledge for the youngsters' chore curriculum in relation to activities such as herding, fishing and hunting, especially at times when boys' fathers would have been away on industrial or military service (for the duties of men in the Mycenaean palatial administration and economy see Ventris and Chadwick 1973, 168-94). For example, the 50-year-old 'veteran hunter' from Tomb $\Lambda$ (late thirteenth to early twelfth century BC) in the Klaus Cemetery at Patras, Achaia, who was buried with his hunting spear and a set of weaving and sewing implements alongside pottery, 'had most probably withdrawn from action and was helping with household chores' (Paschalidis 2014, 828; my translation from the original Greek text). Judging from the nature of his personal belongings, this elderly male could also have been instructing the younger males of the family about hunting and the preparation and repair of hunting nets. Unfortunately, the lack of iconographic and literary evidence prevents any reconstruction of other possible activities involving both children and elderly within the family home, such as instruction by grannies to grand-daughters in relation to cooking, the collection of herbs and vegetables, the feeding of animals, spinning and weaving ( $c f$. Neils and Oakley 2003, 257 no. 61).

\section{Aegean 'Wise-women' and Young Female Patients: A View from Akrotiri}

In addition to the identification of Xeste 3 as a public building serving the performance of gender-separation ceremonies, it has also been viewed as a 'clinic' whose function is emphasised through the important relationship between the medicinal benefits of the plants depicted in the wall paintings and divine blessing (Ferrence and Bendersky 2004, 221). The 'protagonists' are the 'Five Mature Ladies' who alongside their tutelage duties, may have been practitioners of ritual healing. Their specialisations might have included midwifery, nursing and/or magico-ritual attendance, and - like their counterparts and the 'Old Women' of the Hittite medicine (Pringle 1983, 132-4; Beckman 1993, 36-9) - they would have been very experienced and proficient, performing a variety of purificatory and healing rituals, 'working with herbal medicine and performing primitive surgery' (Arnott 1997, 277-8; 2014, 51). The crocus stem painted or tattooed on the cheek of one of the women probably served as an insignia of a healer's status. For Rehak (2002, 50), the floral iconography of Xeste 3 may reflect the local women's experiential knowledge of the medicinal properties of saffron, a knowledge that would have empowered them to experience a personal control of their bodies and thus their lives. The 'wise-women' would have used medicinal plants known for their emmenagogue, labour-stimulating, contraceptive and abortifacient properties (crocus, wild rose, lily, iris, olive and myrtle) to treat the female members of the local community (Hughes-Brock 1999, 288; Rehak 2002, 650; Ferrence and Bendersky 2004; Day 2011, 367-8, n. 7; Vlachopoulos and Zorzos 2014, 194). Young girls might have been members of their 'clientele' too, probably in connection to menarche and associated problems, as may be advocated by a fresh reading of the so-called 'Adorants' fresco on the northern wall and over the Lustral Basin of the building. 


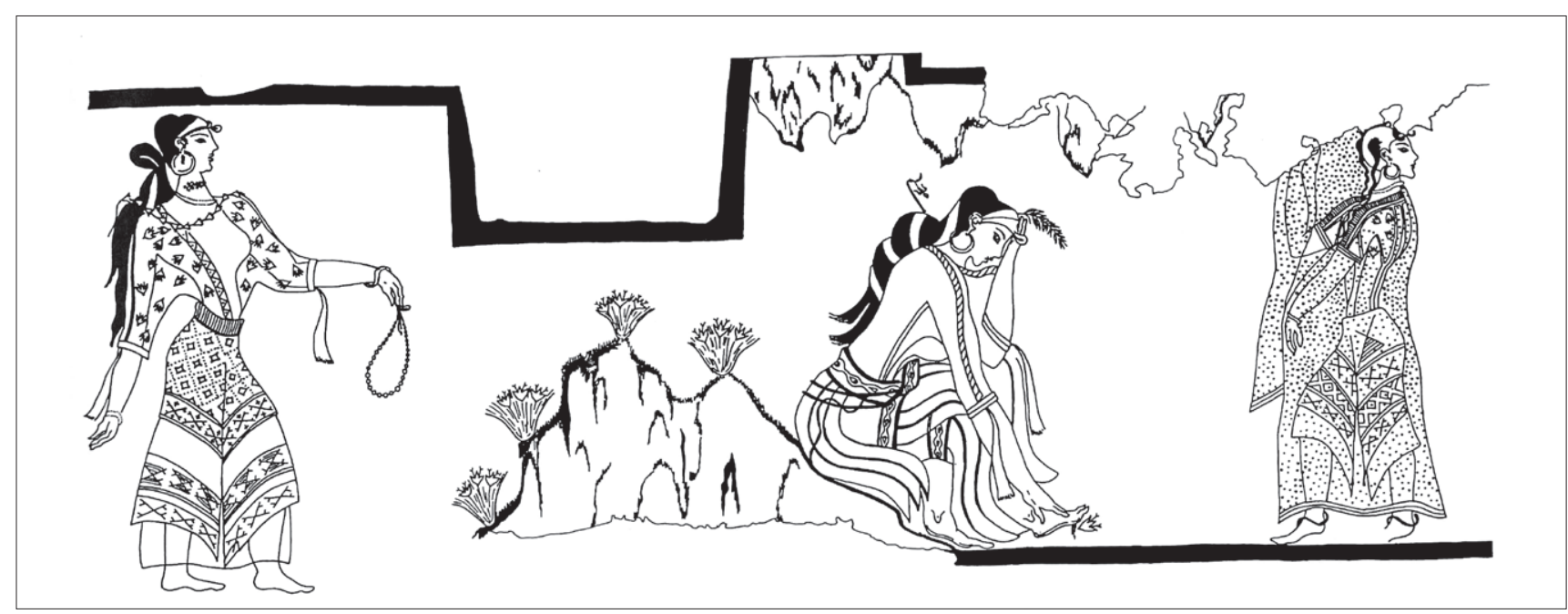

Figure 2: Drawing of the 'Adorants' fresco from the north wall on the ground floor of Room 3a, Xeste 3, Akrotiri, Thera. From left, the 'Necklace Swinger', the 'Wounded Woman' and the 'Veiled Girl'. Original drawing by Paul Rehak, adapted and permission to reproduce by John G. Younger (Younger 2009, pl. XXXIVa).

The 'Adorants' fresco (Fig. 2) depicts three female figures - the 'Necklace Swinger' (around sixteen years-ofage), the 'Wounded Woman' (also around sixteen years old) and the dancing 'Veiled Girl' (approximately ten years old) - in a rocky and crocus-blooming landscape, clearly related to a 'tree-shrine' with a façade of red lilies and crowned by a set of horns of consecration dripping blood that sets the ritual character of the scene; an olive tree is also associated with the ritual structure (Doumas 1992, 129-30). Central to the scene is the so-called 'Wounded Woman' who seats on a crocusstudded knoll with her right leg crossed over the left knee. With the right hand she is reaching to her left foot which bleeds over the bent stem of a crocus flower while, with the left hand, she touches her forehead in a gesture of pain. Her draped but untied apron with lappets is unparalleled in Aegean art. Her unusual belt is decorated with crocus buds (similarly to the garments of the other two figures), and the accessories that adorn her dishevelled and loose hair consist of a hairpin with an iris finial at the nape of her neck and a myrtle twig over her forehead.

Speculative theories put forward for the meaning of this scene range from the illustration of an initiation ceremony related to puberty and womanhood, marriage and defloration, or childbirth, to the depiction of an injury that occurred during crocus-gathering, or of a mythological narrative (e.g. Marinatos 1984, 78-80; 2016; Doumas 1992, 129-30; Barber 1994, 115; Rehak 2002, 41; Vlachopoulos 2007; Günkel-Maschek 2014; Jones 2016; Younger 2016b). Out of all interpretations the most plausible appears to be the one that sees the 'Wounded Woman' experiencing the onset of her first menses (Rehak 2002, 42; 2007, 205-25). This interpretation has a flaw, however, and the figure's full breast development and hairstyle (long brown hair bound in a double knot at the neck, omitting the back-lock), both post-pubescent features, make it seem unlikely that the woman represents an individual about to embark menarche in its simple sense (Chapin 2002, 22; GünkelMaschek 2014, fig. 6). It would therefore be interesting to take Rehak's suggestion a step further and to test the possibility of the scene having served as an illustrated guide to the primitive treatment of primary amenorrhea in the prehistoric Aegean.

Primary amenorrhea is the result of a genetic or anatomic condition in young females who fail to develop menstrual periods by the age of sixteen years in the presence of otherwise normal physical growth and secondary sexual characteristics (Dell 2000,138), potentially just like the 'Wounded Woman'. Based on the illustrated medicinal plants known for their emmenagogue, healing haemostatic and cleansing properties and the figure's blood streaked foot, it is possible to suggest the female healers at Akrotiri may have treated primary amenorrhea through venesection of the saphenous vein in the foot and the use of plant medicines. Support for this interpretation is firmly provided by ancient and folk medicinal practice as in Galen's De Venae Sectione Adversus Erasistratum and his commentary of Hippocrates' Epidemics (Brain 1989, 125), the work of the Muslim physician Ibn al-Jazzār (Bos 1993, 301) and Dionysios Pyrros of Thessaly $(1931,22-3 \$ 26,34 \$ 45)$, not to mention a plethora of ethnographic parallels (see Dammery 2015). Further components that may substantiate this new reading include: 
a) The depiction of associated symptoms of primary amenorrhea such as pain in the lumbar area and in the forehead as understood by the overall pose of the seated figure who leans forward, perhaps in an attempt to relieve abdominal pain or cramps and who is touching her forehead in a possible gesture of pain. Iris, myrtle and crocus have been used since prehistory to relieve headaches, act as haemostatics (hence the bent stem of the crocus flower under the figure's bleeding foot) and to treat gynaecological ailments either through genital washes or uterus suffumigation (e.g. Hippocrates Aphorisms v.28; Eadie 2012, 38; Reinarz 2014, 164). The latter ailments could perhaps explain the loose and peculiar apron worn by the figure.

b) The ritual and healing power of dance (see Dionysios Pyrros of Thessaly 1931, 34\$45, 292\$1140) as suggested by the tiptoe pose of the 'Veiled Girl' whose association with this scene is strongly suggested by her crocus-embroidered bodice and her diaphanous veil, stippled with red (carnelian?) beads that probably symbolise drops of blood (maybe a ritual menstruation-inducing dance).

c) The use of beads for their amuletic healing and symbolic powers in Aegean times (Hughes-Brock 1999; Muskett 2009, 45) may be implied by the necklace held by the 'Necklace Swinger' and the red beads that decorated the veil of the dancing girl (HughesBrock 1999, 278; Jones 2003, 442).

If this new interpretation of the fresco is valid, then such medicinal treatments for young members of the community would have been performed by old/'wise women' who acted as midwives and healers in the service of the Potnia, like the ones represented in the 'Five Mature Ladies' fresco. Although it is not yet securely established exactly how Aegean healers and 'wise women' were trained in pharmacy and healing, it is possible that knowledge might have been inherited within a family of healers, or passed through an apprenticeship relationship, or even acquired through practice and observation (Arnott 2004, 160; 2014, 50).

\section{Till Death do Us Part (or Maybe Not?)}

No parent should have to bury their child, but it is equally painful for a grandparent to lay to rest their grandchild. It is no exaggeration then to classify the scene on the terracotta sarcophagus from Tomb 22 in the cemetery at Tanagra (late thirteenth to early twelfth century BC) as the epitome of the interaction of children and the elderly at death in prehistoric Aegean art
(Gallou-Minopetrou 2015, 62, fig. 2). In this scene two elderly women (identified by their hunchbacked bodies and headscarves) gently lower the shrouded corpse of a child (as suggested by its small size) into a wooden coffin with the aid of a stretcher-like bier. Although it is not possible to establish beyond doubt the exact relationship of the deceased child to the old women (its grandmothers or other close relatives, or maybe elderly women of the community tasked with the preparation and laying out of the dead for burial), this scene provides concrete evidence for the 'interaction' of elderly individuals and children in the sphere of Late Bronze Age Aegean burial customs.

Finally, 'they say an old man is twice a child' (William Shakespeare, Hamlet, Act 2 Scene 2). This could be metaphysically valid in the Late Bronze Age Aegean too with reference to the deposition of clay 'feeding bottles' as grave offerings in both the graves of children and the elderly. Although this class of pottery is traditionally associated with children (PolychronakouSgouritsa 1987; Gallou in press), 'feeding bottles' were sometimes deposited with elderly adults too, probably as drinking aid devices, similar to the Hippocratic bombylioi (Pomadère 2007, 278; Paschalidis 2014, 828). This could therefore point to a kind of shared material culture between infants/toddlers and the elderly in the afterlife.

\section{Aegean Children and the Elderly Combining Forces: Towards the Future}

'Age itself has been a topic of interest to some social archaeologists for some time now ..., but the later part of the life-span tends to be seen as rather problematic and there has so far been a distinct focus on children' (Appleby 2011, 213). Childhood and old age are in the main social and cultural constructions and their definition varies considerably across time, space and cultures. The changing meanings of the ageing process should be seen as archaeologists talk about how elusive the search is for evidence of children in domestic contexts (Lancy 2015, 9), but we are now just starting to understand how equally elusive the elderly are in the material remains of prehistoric societies.

The young have been a fringe interest in Aegean archaeology for quite a long time and it is only recently that scholarship has started to perceive children as 'cultural actors' and agents in the cultures that developed in the region during the Late Bronze Age (some 
scholarship exists for the earlier periods too, Gallou in press). On the other hand, old age and senescence have been virtually neglected, with only a few osteoarchaeological studies providing relevant data in wider evaluations of cemetery populations. Our perception of the elderly as physically decrepit and mentally declining in our industrialised and technological world has no validity when compared to traditional and largely agricultural societies. In these groups the elders, both males and females, are often considered as the keepers of knowledge, and they are the ones who pass valuable survival information and direct memories of times and situations from one generation to the other (Appleby 2011, 233).

Making the young and the old visible in the archaeological record and deciphering the interactions between the two extremes of the life course have therefore the potential to advance our knowledge of the cultural, social and economic workings of the Late Bronze Age Aegean societies. This is because they allow a fuller appreciation of culturally and socially defined age constructions at that time, add to our understanding of the nature and operation of household and family structures, highlight aspects of economic life, professional training and apprenticeship, underscore the role of the elderly in the support and socialisation of children and possibly also the reciprocal contribution of children in later life care, and provide insights into the material culture shared between the two age cohorts in life and in death. There is still a long way to go but, as this study has aimed to show, it is possible to start identifying the impact of youth-elderly interaction in the prehistoric cultures of the Aegean through the application of an interdisciplinary approach. There is no foot too small or too old that it cannot leave an imprint on this world, past and present.

\section{Acknowledgements}

I would like to warmly thank Professor Grete Lillehammer and Professor Eileen Murphy for kindly inviting me to contribute to the volume. This study has benefited from long discussions with Sarantos Minopetros who provided interesting insights into the material examined and, in particular, the interpretation of the 'Adorants' Fresco from Akrotiri and ethnographic parallels, and from the useful comments provided by the anonymous reviewer. Many thanks are also owed to Professors Stephanie Budin and John Younger for permission to reproduce the images used in the text.

\section{Notes}

1. e.g. Alberti 2002; Chapin 2009; 2011; 2012; Kokkinidou and Nikolaidou 2009, footnote 10; Kopaka 2009; Ruppenstein 2010; Budin 2011; Driessen 2012; Hitchcock and Nikolaidou 2013; Olsen 2014; Triantaphyllou 2016, 160; Schepartz et al. 2017.

2. Note also Triantaphyllou's $(2016,161)$ recent call for a discussion into the actual evidence of human remains in the prehistoric Aegean and their biological attributes with reference to the perception of age; $c f$. Mays et al. 2017.

3. 'Wie keine andere verdeutlicht die historische Perspektive, dass Alter keine anthropologische, biologische oder kalendarische Konstante ist. (Hohes) Alter ist ein soziokulturelles Konstrukt, das in der jeweiligen Gesellschaft geprägt wird, historisch entsteht und sich historisch verändert. Dieser Sachverhalt betrifft den zahlenmäßigen Anteil der Alten an der Gesamtbevölkerung, ihre Lebensbedingungen und schließlich die Antwort auf die Frage, wer überhaupt als ,alt' gilt. Alter war und ist zudem gekennzeichnet durch geschlechts-, standes - und schichtenspezifische und nicht zuletzt individuelle Ausprägungen in der jeweiligen Zeit' (Luh 2003, 315).

4. Note though Rehak's $(1999,13 ; 2002,48-50)$ suggestion that this may be a sign of vitamin A or riboflavin deficiency, rather than of senescence.

5. If it were not for the funerary inscription, though, the younglooking adult female figure would have been most probably identified as the mother of the child, not its grandmother.

6. 'kourotrophic' signifying the rearing of youths, especially in the context of prehistoric and ancient Greece.

${ }^{7}$ wo-di-je-ja de-mi-ni-ja

ma-no a-re-ka-sa-da-ra- $\{k a\}$

ri-su-ra qo-ta-qe

e-ri-tu-pi-na te-o-do-ra-qe

o-to-wo-wi-je tu-ka-te-qe

a2-ne-a tu-ka-te-qe

pi-ro-wo-na ki-ra-qe

pu-ka-ro ke-ti-de-qe

...

], i-ri-[.] (1) ke-ra-so ki-ra-qe

\section{References}

Agarwal, S. C. 2012. The past of sex, gender and health: bioarchaeology of the aging skeleton. American Anthropologist 114, 322-35.

Alberti, B. 2002. Gender and the figurative art of Late Bronze Age Knossos, pp. 98-117 in Hamilakis, Y. (ed.), Labyrinth Revisited. Rethinking 'Minoan' Archaeology. Oxford: Oxbow Books.

Appleby, J. E. P. 2010.Why we need an archaeology of old age, and a suggested approach. Norwegian Archaeological Review 43, 145-68.

Appleby, J. E. P. 2011. Bodies, burials and ageing: accessing the temporality of old age in prehistoric societies. Oxford Journal of Archaeology 30, 231-46.

Arnott, R. 1997. Surgical practice in the prehistoric Aegean. Medizinhistorisches Journal 32, 249-78.

Arnott, R. 2014. Healers and medicines in the Mycenaean Greek texts, pp. 44-53 in Michaelides, D. (ed.), Medicine and Healing in the Ancient Mediterranean World. Oxford: Oxbow Books.

Barber, E. W. 1994. Women's Work. The First 20,000 years. 
Women, Cloth, and Society in Early Times. London: W.W. Norton \& Co.

Baxter, J. E., Vey, S., McGuire, E. H., Conway, S. and Blom, D. E. 2017. Reflections on interdisciplinarity in the study of childhood in the past. Childhood in the Past 10, 1-15.

Beckman, G. 1993. From cradle to grave: women's role in Hittite medicine and magic. Journal of Ancient Civilizations 8, 25-39.

Betts, J. H. 2015. The seal from Shaft Grave Gamma - A 'Mycenaean Chieftain'?, pp. 289-95 in Betancourt, P. P. (ed.), Temple University Aegean Symposium: A Compendium. Philadelphia: INSTAP Academic Press.

Bos, G. 1993. Ibn al-Jazzar on women's diseases and their treatment. Medical History 37, 296-312.

Bourbou, C. 2013. The imprint of emotions surrounding the death of children in antiquity, pp. 331-50 in Chaniotis, A. and Ducrey, P. (eds.), Unveiling Emotions II. Emotions in Greece and Rome: Texts, Images, Material Culture. Stuttgart: Franz Steiner Verlag.

Brain, P. 1989. Galen on Bloodletting: A Study of the Origins, Development and Validity of his Opinions, with a Translation of the Three Works. Cambridge: Cambridge University Press.

Budin, S. 2011. Images of Woman and Child from the Bronze Age: Reconsidering Fertility, Maternity, and Gender in the Ancient World. Cambridge: Cambridge University Press.

Budin, S. 2014. Mother or sister? Finding adolescent girls in Minoan figural art, pp. 105-16 in Moraw, S. and Kieburg, A. (eds.), Mädchen im Altertum. Münster: Waxmann.

Budin, S. 2016. Maternity in the Bronze Age Aegean, pp. 595607 in Budin, S. and MacIntosh Turfa, J. (eds.), Women in Antiquity: Real Women Across the Ancient World. London: Routledge.

Carlier, P. 1999. Les mentions de la parenté dans les textes mycéniens, pp. 185-93 in Deger-Jalkotzy, S., Hiller, S. and Panagl, O. (eds.), Floreant Studia Mycenaea. Akten sed X. Internationalen Mykenologischen Colloquiums in Salzburg vom 1.-5. Mai 1995. Band II. Vienna: Verlag der Österreichischen Akademie der Wissenschaften.

Cave, C. and Oxenham, M. 2016. Identification of the archaeological 'invisible elderly': an approach illustrated with an Anglo-Saxon example. International Journal of Osteoarchaeology 26, 163-75.

Chapin, A. P. 2002. Maidenhood and marriage: the reproductive lives of the girls and women from Xeste 3, Thera. Aegean Archaeology 4, 7-25.

Chapin, A. P. 2007. Boys will be boys: youth and gender identity in the Theran frescoes, pp. 229-55 in Cohen, A. and Rutter, J. B. (eds.), Constructions of Childhood in Ancient Greece and Italy (Hesperia Supplement 41). Princeton: The American School of Classical Studies at Athens.

Chapin, A. P. 2009. Constructions of male youth and gender in Aegean art: the evidence from Late Bronze Age Crete and Thera, pp. 175-82 in Kopaka, K. (ed.), Fylo: Engendering Prehistoric 'Stratigraphies' in the Aegean and the Mediterranean. Proceedings of an International Conference, University of Crete, Rethymno 2-5 June 2005 (Aegaeum 30). Liège and Austin: Université de Liège and University of Texas at Austin.

Chapin, A. P. 2011. Gender and coalitional power in the miniature frescoes of Crete and the Cycladic islands, pp. 507-22 in Andreadaki-Vlazaki, M. and Papadopoulou, E.

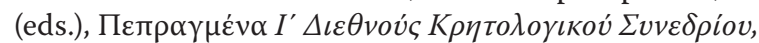

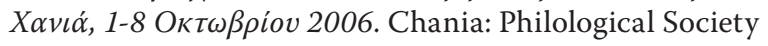
'O Chrysostomos'.

Chapin, A. P. 2012. Do clothes make the man (or woman?): sex, gender, costume, and the Aegean color convention, pp. 297-304 in Nosch M-L. and Laffineur, R. (eds.), Kosmos: Jewellery, Adornment and Textiles in the Aegean Bronze Age. Proceedings of the 13th International Aegean Conference, University of Copenhagen, Danish National Research Foundation's Centre for Textile Research, 21-26 April 2010 (Aegaeum 33). Liège: Peeters.

Crawford, S. 2017. SSCIP: the first 10 years. Childhood in the Past 10, 10-15.

Crowley, J. L. 2013. The Iconography of Aegean Seals (Aegaeum 34). Liège: Peeters.

Dammery, S. 2015. The First Blood. A Cultural Study of Menarche. Clayton: Monash University Publishing.

Davis, E. N. 1986. Youth and age in the Thera frescoes. American Journal of Archaeology 90, 399-406.

Day, J. 2011. Crocuses in context: a diachronic survey of the crocus motif in the Aegean Bronze Age. Hesperia 80, 33779.

Dell, M. L. 2000. Will my time ever come? On being single, pp. 311-22 in Stevenson-Moessner, J. (ed.), In Her Own Time: Women and Developmental Issues in Pastoral Care. Minneapolis: Fortress Press.

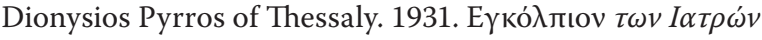

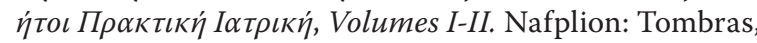
Ioannidis and Athenasiadis.

Doumas, C. 1992. The Wall-Paintings of Thera. Athens: The Thera Foundation, Petros M. Nomikos.

Doumas, C. 2000. Age and gender in the Theran wall paintings, pp. 971-81 in Sherratt, S. (ed.), The Wall Paintings of Thera. Proceedings of the First International Symposium, Petros M. Nomikos Conference Centre, Thera, Hellas, 30 August-4 September 1997, Vol. II. Athens: Thera Foundation, Petros M. Nomikos.

Driessen, J. 2012. A matrilocal house society in Pre- and Protopalatial Crete?, pp. 358-83 in Schoep, I. Tomkins, P. and Driessen, J. (eds.), Back to the Beginning: Reassessing Social and Political Complexity on Crete during the Early and Middle Bronze Age. Oxford: Oxbow Books.

Duhoux, Y. 2008. Mycenaean anthology, pp. 243-393 in Duhoux, Y. and Morpurgo Davies, A. (eds.), A Companion to Linear B: Mycenaean Texts and their World. Louvain-laNeuve: Peeters.

Eadie, M. J. 2012. Headache: Through the Centuries. Oxford: Oxford University Press.

Efkleidou, K. 2002-03. The status of 'outsiders' within Mycenaean Pylos: issues of ethnic identity, incorporation or marginality. Minos 37-8, 269-91.

Evans, A. J. 1930. The Palace of Minos at Knossos, Vol. 3. London: Macmillan.

Ferrence, S. C. and Bendersky, G. 2004. Therapy with saffron and the goddess at Thera. Perspectives in Biology and Medicine 47, 199-226.

Forsdyke, J. 1954. The 'Harvester' Vase of Hagia Triada. Journal of the Warburg and Courtauld Institutes 17, 1-9.

Gallou, C. 2004. More than little perishers: the case of 
child burials in Mycenaean Greece. EthnographischArchäologische Zeitschrift 46, 365-75.

Gallou, C. 2010. Children at work in Mycenaean Greece (ca. 1680-1050 BC): a brief survey, pp. 162-7 in Brockliss, L. and Montgomery, H. (eds.), Children and Violence from the Greeks to the Present. Oxford: Oxbow Books.

Gallou, C. in press. Children and death in the Bronze and Early Iron Age Aegean, in Beaumont, L., Dillon, M. and Harrington, N. (eds.), Children in Antiquity: Perspectives and Experiences of Childhood in the Ancient Mediterranean (Rewriting Antiquity). London: Routledge.

Gallou-Minopetrou, C. 2015. 'What would the world be to us if the children were no more?': the archaeology of children and death in LH IIIC Greece, pp. 57-67 in Theodoropoulou Polychroniadis, Z. and Evely, D. (eds.), Aegis: Essays in Mediterranean Archaeology Presented to Matti Egon by the Scholars of the Greek Archaeological Committee UK. Oxford: Archaeopress.

Garland, R. 1990. The Greek Way of Life. From Conception to Old Age. New York: Cornell University Press.

Gates, C. 1992. Art for children in Mycenaean Greece, pp. 16171 in Laffineur, R. and Crowley, J. L. (eds.), EIKON. Aegean Bronze Age Iconography: Shaping a Methodology. 4th International Aegean Conference, University of Tasmania, Hobart, 6-9 April 1992 (Aegaeum 8). Liège: Université de Liège.

Georgas, J., Mylonas, K., Bafiti, T., Poortinga, Y., Christakopoulou, S. Kagitcibasi, C., Kwak, K., Ataca, B., Berry, J., Orung, S., Sunar, D., Charalambous, N., Goodwin, R., Wang, W-Z., Angleitner, A., Stepanikova, I., Pick, S., Givaudan, M., Zhuravliova-Gionis, I., Konantambigi, R., Gelfand, M. J., Marinova, V., McBride-Chang, C. and Kodiç, Y. 2001. Functional relationships in the nuclear and extended family: a 16-culture study. International Journal of Psychology 36, 289-300.

German, S. C. 2000. The human form in the Late Bronze Age Aegean, pp. 95-110 in Rautman, A. E. (ed.), Reading the Body: Representations and Remains in the Archaeological Record. Philadelphia: University of Pennsylvania Press.

Gessell, G. 2000. Blood on the horns of consecration?, pp. 947-95 in Sherratt, S. (ed.), The Wall Paintings of Thera. Proceedings of the First International Symposium, Petros M. Nomikos Conference Centre, Thera, Hellas, 30 August-4. September 1997, Vol. II. Athens; Thera Foundation, Petros M. Nomikos.

Günkel-Maschek, U. 2014. Time to grow up, girl! Childhood and adolescence in Bronze Age Akrotiri, Thera, pp. 117-33 in Moraw, S. and Kieburg, A. (eds.), Mädchen im Altertum. Münster: Waxmann.

Hank, K. and Buber, I. 2009. Grandparents caring for their grandchildren: findings from the 2004 'Survey of Health, Ageing, and Retirement in Europe'. Journal of Family Issues 30, 53-73.

Hawkes, K., O'Connell, J. and Blurton-Jones, N. 2000. Hadza women's time allocation, offspring provisioning, and the evolutions of long postmenopausal life spans. Current Anthropology 38, 551-77.

Hitchcock, L. and Nikolaidou, M. 2013. Gender in Greek and Aegean prehistory, pp. 502-25 in Bolger, D. (ed.), A Companion to Gender Prehistory. Chichester: WileyBlackwell.

Hrdy, S. B. 2009. Mothers and Others: The Evolutionary Origins of Mutual Understanding. Cambridge MA:
Harvard University Press.

Hughes-Brock, H. 1999. Mycenaean beads: gender and social contexts. Oxford Journal of Archaeology 18, 277-96.

Ingvarsson-Sundström, A. 2002. Small parts of society skeletal remains of children at Asine, pp. 49-56 in Wells, B. (ed.), New Research on Old Material from Asine and Berbati in Celebration of the Fiftieth Anniversary of the Swedish Institute at Athens. Stockholm: Svenska Institutet i Athen.

Ingvarsson-Sundström, A. 2008. Asine III: Supplementary Studies on the Swedish Excavations 1922-1930, Volume 2. Children Lost and Found: A Bioarchaeological Study of Middle Helladic Children in Asine with a Comparison to Lerna. Stockholm: Svenska Institutet i Athen.

Jones, B. R. 2003. Veils and mantles: an investigation of the construction and function of the costumes of the veiled dancer from Thera and the camp stool banqueter from Knossos, pp. 441-50 in Foster, K. O. and Laffineur, R. (eds.), Metron: Measuring the Aegean Bronze Age. Proceedings of the 9th International Aegean Conference, New Haven, Yale University, 18-21 April 2002 (Aegaeum 24). Liège: Université de Liège.

Jones, B. R. 2016. A new reading of the fresco program and the ritual in Xeste 3, Thera, pp. 365-73 in Alram-Stern, E., Blakolmer, F., Deger-Jalkotzy, S., Laffineur, R. and Weilhartner, J. (eds.), Metaphysis: Ritual, Myth and Symbolism in the Aegean Bronze Age. Proceedings of the 15th International Aegean Conference, Vienna, Institute for Oriental and European Archaeology, Aegean and Anatolia Department, Austrian Academy of Sciences and Institute of Classical Archaeology, University of Vienna, 22-25 April 2014 (Aegaeum 39). Liège: Peeters.

Kirk, G. 1973. Old Age and Maturity in Ancient Greece. Leiden: Brill.

Koehl, R. B. 2001. The 'sacred marriage' in Minoan religion and ritual, pp. 237-43 in Laffineur, R. and Hägg, R. (eds.), Potnia: Deities and Religion in the Aegean Bronze Age. Proceedings of the 8th International Aegean Conference, Göteborg University, 12-15 April 2000 (Aegaeum 22). Liège: Université de Liège.

Kokkinidou, D. and Nikolaidou, M. 2009. Feminism and Greek archaeology: an encounter long over-due, pp. 25-37 in Kopaka, K. (ed.), Fylo: Engendering Prehistoric 'Stratigraphies' in the Aegean and the Mediterranean. Proceedings of an International Conference, University of Crete, Rethymno 2-5 June 2005 (Aegaeum 30). Liège and Austin: Université de Liège and University of Texas at Austin.

Kopaka, K. 2009. Mothers in Aegean stratigraphies? The dawn of ever-continuing engendered life cycles, pp. 183-95 in Kopaka, K. (ed.), Fylo: Engendering Prehistoric 'Stratigraphies' in the Aegean and the Mediterranean. Proceedings of an International Conference, University of Crete, Rethymno 2-5 June 2005 (Aegaeum 30). Liège and Austin: Université de Liège and University of Texas at Austin.

Lagia, A., Petroutsa, E. and Manolis, S. 2007. Health and diet during the Middle Bronze Age in the Peloponnese: the site of Kouphovouno, pp. 313-28 in Mee, C. and Renard, J. (eds.), Cooking up the Past: Food and Culinary Practices in the Neolithic and Bronze Age Aegean. Oxford: Oxbow Books.

Lancy, D. 2015. The Anthropology of Childhood: Cherubs, 
Chattel, Changelings (second edition). Cambridge: Cambridge University Press.

Lebegyev, J. 2009. Phases of childhood in Early Mycenaean Greece. Childhood in the Past 2, 5-32.

Lewis, M. 2007. The Bioarchaeology of Children: Perspectives from Biological and Forensic Anthropology. Cambridge: Cambridge University Press.

Lillehammer, G. 1989. A child is born. The child's world in an archaeological perspective. Norwegian Archaeological Review 22, 89-105.

Lillehammer, G. 2010. Introduction to socialisation, pp. 9-19 in Lillehammer, G. (ed.), Socialisation. Recent Research on Childhood and Children in the Past (AmS-Skrifter 23). Stavanger: Stavanger Museum of Archaeology, University of Stavanger

Lillehammer, G. 2015. 25 Years with the 'child' and the archaeology of childhood. Childhood in the Past 8, 78-86.

Luh, A. 2003. Das 'Goldene Zeitalter der Alten'? Alter in historischer perspektive. Zeitschrift für Gerontologie und Geriatrie Deutsche Gesellschaft für Gerontologie und Geriatrie 36, 303-16.

Marinatos, N. 1984. Art and Religion in Thera. Reconstructing a Bronze Age Society. Athens: D. and I. Mathioulakis.

Marinatos, N. 2005. The ideals of manhood in Minoan Crete, pp. 229-40 in Morgan, L. (ed.), Aegean Wall Painting: A Tribute to Mark Cameron. London: British School at Athens.

Marinatos, N. 2010. Minoan Kingship and the Solar Goddess: A Near Eastern Koine. Urbana: University of Illinois Press.

Marinatos, N. 2016. Myth, ritual, symbolism and the solar goddess in Thera, pp. 3-11 in Alram-Stern, E., Blakolmer, F., Deger-Jalkotzy, S., Laffineur, R. and Weilhartner, J. (eds.), Metaphysis: Ritual, Myth and Symbolism in the Aegean Bronze Age. Proceedings of the 15th International Aegean Conference, Vienna, Institute for Oriental and European Archaeology, Aegean and Anatolia Department, Austrian Academy of Sciences and Institute of Classical Archaeology, University of Vienna, 22-25 April 2014 (Aegaeum 39). Liège: Peeters.

Mays, S., Gowland, R., Halcrow, S. and Murphy, E. 2017. Child bioarchaeology: perspectives on the past 10 years. Childhood in the Past 10, 1-19.

Morgan, L. 1990. Island iconography: Thera, Kea, Milos, pp. 252-66 in Hardy, D. A., Doumas, C. G., Sakellarakis, J. A. and Warren, P. M. (eds.), Thera and the Aegean World III. Vol. 1: Archaeology. Proceedings of the Third International Congress, Santorini, Greece, 3-9 September 1989. London: The Thera Foundation.

Morgan, L. 2000. Form and meaning in figurative painting, pp. 925-46 in Sherratt, S. (ed.), The Wall Paintings of Thera. Proceedings of the First International Symposium, Petros M. Nomikos Conference Centre, Thera, Hellas, 30 August-4 September 1997, Vol. II. Athens: Thera Foundation, Petros M. Nomikos.

Morgan, L. 2005. New discoveries and new ideas in Aegean wall painting, pp. 229-40 in Morgan, L. (ed.), Aegean Wall Painting: A Tribute to Mark Cameron. London: British School at Athens.

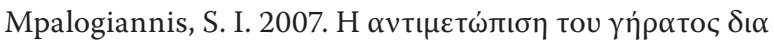

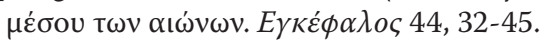

Murray, S. P. 2016. Patterned textiles as costume in Aegean art, pp. 43-103 in Shaw, M. C. and Chapin, A. (eds.), Woven Threads: Patterned Textiles of the Aegean Bronze Age.
Oxford: Oxbow Books.

Muskett, G. 2009. Rites of passage for young children in Mycenaean Greece. Childhood in the Past 1, 38-48.

Mylonas, G. 1983. Mycenae Rich in Gold. Athens: Ekdotiki Athinon.

Mylonas Shear, I. 1987. The Panagia Houses at Mycenae. Philadelphia: The University Museum, University of Pennsylvania.

Neils, J. and Oakley, J. H. (eds.), 2003. Coming of Age in Ancient Greece: Images of Childhood from the Classical Past. New Haven: Yale University Press.

Nixon, L. 1999. Women, children, and weaving, pp. 561-7 in Betancourt, P. P., Karageorghis, V., Laffineur, R. and Niemeier W-D. (eds.), Meletemata: Studies in Aegean Archaeology presented to Malcolm H. Wiener as he Enters his 65th Year. Vol. II. Liège and Austin: University de Liège and University of Texas at Austin.

Nordquist, G. and Ingvarsson-Sundström, A. 2005. Live hard, die young: Middle and early Late Helladic mortuary remains of children from the Argolid in social context, pp. 156-74 in Dakouri-Hild, A. and Sherratt, S. (eds.), Autochthon: Papers presented to O. T. P. K. Dickinson on the Occasion of his Retirement, Institute of Classical Studies, University of London, 9 November 2005 (BAR International Series 1432). Oxford: Archaeopress.

Nosch, M-L. 2001. Kinderarbeit in der mykenischen Palastzeit, pp. 37-43 in Blakolmer, F. and Szemethy, H. D. (eds.), Akten des 8. Österreichischen Archäologentages am Institut für Klassische Archäologie der Universität Wien vom 23. bis 25. April 1999. Vienna: Phoibos Verlag.

Nosch, M-L. 2003. The women at work in the Linear B tablets, pp. 12-26 in Lovén, L. L. and Strömberg, A. (eds.), Gender, Cult, and Culture in the Ancient World from Mycenae to Byzantium: Proceedings of the Second Nordic Symposium on Gender and Women's History in Antiquity, Helsinki, 2022 October 2000 (SIMA-166, PB). Sävedalen: Paul Åströms Förlag.

Olsen, B. 1998. Women, children and the family in the Late Bronze Age: differences in Minoan and Mycenaean constructions of gender. World Archaeology 29, 380-92.

Olsen, B. 2014. Women in Mycenaean Greece: The Linear B tablets from Pylos and Knossos. London: Routledge.

Palaima, T. 2014. Pylos Tablet Vn 130 and the Pylos perfume industry, pp. 83-90 in Nakassis, D., Gulizio, J. and James, S. A. (eds.), KE-RA-ME-JA: Studies Presented to Cynthia W. Shelmerdine. Philadelphia: INSTAP Academic Press.

Papageorgiou, I. 2008. Children and adolescents in Minoan Crete, pp. 89-95 in Andreadaki-Vlazaki, M., Rethemiotakis, G. and Dimopoulou-Rethemiotaki, N. (eds.), From the Land of the Labyrinth: Minoan Crete, 3000-1100 B.C. Volume 2: Essays. New York: Alexander S. Onassis Public Benefit Foundation.

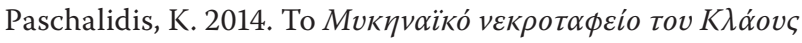

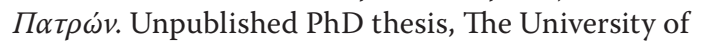
Ioannina.

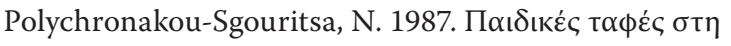

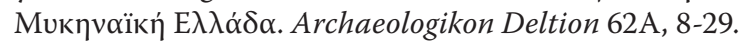

Pomadère, M. 2007. Des enfants nourris au biberon à l'Âge du Bronze?, pp. 270-89 in Mee, C. and Renard, J. (eds.), Cooking up the Past: Food and Culinary Practices in the Neolithic and Bronze Age Aegean. Oxford: Oxbow Books.

Pomadère, M. 2012. Dressing and adorning children in the Aegean Bronze Age: material and symbolic protections as 
well as marks of an age group?, pp. 433-9 in Nosch, M-L. and Laffineur, R. (eds.), Kosmos: Jewellery, Adornment and Textiles in the Aegean Bronze Age. Proceedings of the 13th International Aegean Conference, University of Copenhagen, Danish National Research Foundation's Centre for Textile Research, 21-26 April 2010 (Aegaeum 33). Liège: Peeters.

Porter, R. 2000. The flora of the Theran wall paintings: living plants and motifs - sea lily, crocus, iris and ivy, pp. 603-30 in Sherratt, S. (ed.), The Wall Paintings of Thera. Proceedings of the First International Symposium, Petros M. Nomikos Conference Centre, Thera, Hellas, 30 August-4 September 1997, Vol. II. Athens: Thera Foundation, Petros M. Nomikos.

Pringle, J. 1983. Hittite birth ritual, pp. 128-41 in Cameron, A. and Kuhrt, A. (eds.), Images of Women in Antiquity. London: Routledge.

Rehak, P. 1998. The construction of gender in late Bronze Age Aegean art: A prolegomenon, pp. 191-8 in Casey, M., Donlon, D., Hope, J. and Welfare, S. (eds.), Redefining Archaeology: Feminist Approaches. Canberra: ANH Publications, RSPAS.

Rehak, P. 1999. The Aegean landscape and the body: A new interpretation of the Thera frescoes, pp. 11-22 in Wicker, N. L and Arnold, B. (eds.), From the Ground Up: Beyond Gender Theory in Archaeology: Proceedings of the Fifth Gender and Archaeology Conference, University of Wisconsin-Milwaukee, October 1998 (BAR International Series 812). Oxford: Archaeopress.

Rehak, P. 2002. Imag(in)ing a women's world in Bronze Age Greece: the frescoes from Xeste 3 at Akrotiri, Thera, pp. 34-59 in Rabinowitz, N. S. and Auanger, L. (eds.), Among Women: From the Homosocial to the Homoerotic in the Ancient World. Austin: University of Texas Press.

Rehak, P. 2004. Crocus costumes in Aegean Art, pp. 85-100 in Chapin, A. (ed.), Charis: Essays in Honor of Sara A. Immerwahr (Hesperia Supplement 33). Princeton: The American School of Classical Studies at Athens.

Rehak, P. 2007. Children's work: girls as acolytes in Aegean ritual and cult, pp. 205-25 in Cohen, A. and Rutter, J. B (eds.), Constructions of Childhood in Ancient Greece and Italy (Hesperia Supplement 41). Princeton: The American School of Classical Studies at Athens.

Rehak, P. (edited by J. Younger) 2009. Some unpublished studies by Paul Rehak on gender in Aegean art, pp. 1117 in Kopaka, K. (ed.), Fylo: Engendering Prehistoric 'Stratigraphies' in the Aegean and the Mediterranean. Proceedings of an International Conference, University of Crete, Rethymno 2-5 June 2005 (Aegaeum 30). Liège and Austin: Université de Liège and University of Texas at Austin.

Reinarz, J. 2014. Historical Perspectives on Smell. Champaign: University of Illinois Press.

Richardson, B. E. 1933. Old Age Among the Ancient Greeks: The Greeks Portrayal of Old Age in Literature, Art, and Inscriptions, with a Study of the Duration of Life Among the Ancient Greeks on the Basis of Inscriptional Evidence. Baltimore: Johns Hopkins Press.

Ruppenstein, F. 2010. Gender and regional differences in Middle Helladic burial customs, pp. 431-9 in PhilippaTouchais, A., Touchais, G., Voutsaki, S. and Wright, J. (eds.), Mesohelladika. La Grèce Continentale au Bronze Moyen. Actes du Colloque International Organisé par
l'École Française d'Athènes, en Collaboration avec l'American School of Classical Studies at Athens et le Netherlands Institute in Athens, Athènes, 8-12 mars 2006 (BCH Supplement 52). Athens: École Française d'Athènes.

Rutter, J. B. 2003. Children in Aegean prehistory, pp. 30-57 in Neils, J. and Oakley, J. H. (eds.), Coming of Age in Ancient Greece: Images of Childhood from the Classical Past. New Haven: Yale University Press.

Sarpaki, A. 2000. Plants chosen to be depicted on Theran wall paintings: tentative interpretations, pp. 657-80 in Sherratt, S. (ed.), The Wall Paintings of Thera. Proceedings of the First International Symposium, Petros M. Nomikos Conference Centre, Thera, Hellas, 30 August-4 September 1997, Vol. II. Athens: Thera Foundation, Petros M. Nomikos.

Schepartz, L. A., Stocker, S., Davis, J. L., Papathanasiou, A., Miller-Antonio, S., Murphy, J. M. A., Richards, M. and Malapani, E. 2017. Mycenaean hierarchy and gender roles: diet and health inequalities in Late Bronze Age Pylos, Greece, pp. 141-72 in Klaus, H. D., Harvey, A. R and Cohen, M. N. (eds.), Bones of Complexity: Bioarchaeological Case Studies of Social Organization and Skeletal Biology. Gainesville: University Press of Florida.

Shank, E. 2012. The jewelry worn by the procession of mature women from Xeste 3, Akrotiri, pp. 559-65 in Nosch, M-L. and Laffineur, R. (eds.), Kosmos: Jewellery, Adornment and Textiles in the Aegean Bronze Age. Proceedings of the 13th International Aegean Conference, University of Copenhagen, Danish National Research Foundation's Centre for Textile Research, 21-26 April 2010 (Aegaeum 33). Liège: Peeters.

Shelmerdine, C. W. 2008. Mycenaean society, pp. 115-58 in Duhoux, Y. and Morpurgo Davies, A. (eds.), A Companion to Linear B: Mycenaean Greek Texts and their World, Vol. 1 (Bibliothèque des cahiers de l'Institut de Linguistique de Louvain 120). Leuven: Peeters.

Shelmerdine, C. W. 2016. Women in the Mycenaean economy, pp. 618-34 in Budin, S. and MacIntosh Turfa, J. (eds.), Women in Antiquity: Real Women Across the Ancient World. London: Routledge.

Svensson-Dianellou, A., Smith, P. and Mestheneos, E. 2010. Family help by Greek grandparents. Journal of Intergenerational Relationships 8, 249-63.

Triantaphyllou, S. 2010. Prospects for reconstructing the lives of Middle Helladic populations in the Argolid: past and present of human bone studies, pp. 441-5 in Philippa-

Touchais, A., Touchais, G., Voutsaki, S. and Wright, J. (eds.), Mesohelladika. La Grèce Continentale au Bronze Moyen. Actes du Colloque International Organisé par l'École Française d'Athènes, en Collaboration avec l'American School of Classical Studies at Athens et le Netherlands Institute in Athens, Athènes, 8-12 Mars 2006 (BCH Supplement 52). Athens: École Française d'Athènes.

Triantaphyllou, S. 2016. Constructing identities by ageing the body in the prehistoric Aegean: the view through the human remains, pp. 160-8 in Mina, M., Triantaphyllou, S. and Papadatos, Y. (eds.), An Archaeology of Prehistoric Bodies and Embodied Identities in the Eastern Mediterranean. Oxford: Oxbow Books.

Valentine, K., Li, N. and Yong, J. 2016. Competitive motherhood from a comparative perspective, pp. 479-504 in Fisher, M. (ed.), The Oxford Handbook of Women and Competition. Oxford: Oxford University Press.

Ventris, M. and Chadwick, J. 1973. Documents in Mycenaean 
Greek (second edition). Cambridge: Cambridge University Press.

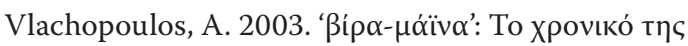

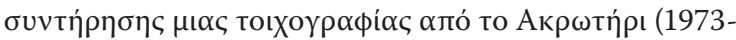
2003), pp. 505-26 in Vlachopoulos, A. and Mpirtacha, K.

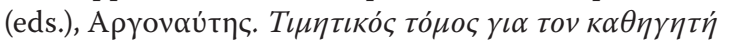

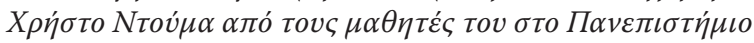
$A \theta \eta v \omega ́ v$ (1980-2000). Athens: I. Kathimerini A. E.

Vlachopoulos, A. 2007. Mythos, Logos and Eikon. Motifs of early Greek poetry in the wall paintings of Xeste 3, pp. 107-18 in Morris, S. P. and Laffineur, R. (eds.), Epos: Reconsidering Greek Epic and Aegean Bronze Age Archaeology. Proceedings of the 11th International Aegean Conference, Los Angeles, UCLA - The J. Paul Getty Villa, 20-23 April 2006 (Aegaeum 28). Liège: Peeters.

Vlachopoulos, A. 2008. The wall paintings from the Xeste 3 Building at Akrotiri: towards an interpretation of the iconographic programme, pp. 451-65 in Brodie, N., Doole, J., Gavalas, G. and Renfrew, C. (eds.), Opi $\zeta \omega v:$ A Colloquium on the Prehistory of the Cyclades. Cambridge: McDonald Institute Monographs.

Vlachopoulos, A. 2010. L'espace rituel revisité: architecture et iconographie dans la Xestè 3 d'Akrotiri, Théra, pp. 173-98 in Boehm, I. and Müller-Celka, S. (eds.), Espace Civil, Espace religieux en Égée Durant la Période Mycénienne: Approches Épigraphique, Linguistique et Archéologique. Actes des Journées d'Archéologie et de Philologie Mycéniennes Tenues à la Maison de l'Orient et de la Méditerranée - Jean Pouilloux les 1 er Février 2006 et 1 er Mars 2007 (Travaux de la Maison de l'Orient et de la Méditerranée 54). Lyon: Maison de l'Orient et de la Méditerranée, Jean Pouilloux.

Vlachopoulos, A. 2016. Images of physis or perceptions of metaphysis? Some thoughts on the iconography of the Xeste 3 building at Akrotiri, Thera, pp. 375-85 in AlramStern, E., Blakolmer, F., Deger-Jalkotzy, S. Laffineur, R. and Weilhartner, J. (eds.), Metaphysis: Ritual, Myth and
Symbolism in the Aegean Bronze Age. Proceedings of the 15th International Aegean Conference, Vienna, Institute for Oriental and European Archaeology, Aegean and Anatolia Department, Austrian Academy of Sciences and Institute of Classical Archaeology, University of Vienna, 22-25 April 2014 (Aegaeum 39). Liège: Peeters.

Vlachopoulos, A. and Zorzos, L. 2014. Physis and Techne on Thera: reconstructing Bronze Age environment and land-use based on new evidence from phytoliths and the Akrotiri wall-paintings, pp. 183-97 in Touchais, G., Laffineur, R. and Rougemont, F. (eds.), Physis: l'Environnement Naturel et la Relation Homme-milieu dans le Monde Égéen Protohistorique. Actes de la 14e Rencontre Égéenne Internationale, Paris, Institut National d'Histoire de l'Art (INHA), 11-14 Décembre 2012 (Aegaeum 37). Liège: Peeters.

Welinder, S. 2001. The archaeology of old age. Current Swedish Archaeology 9, 163-78.

Younger, J. G. 2009. 'We are woman': girl, maid, matron in Aegean art, pp. 207-12 in Kopaka, K. (ed.), Fylo: Engendering Prehistoric 'Stratigraphies' in the Aegean and the Mediterranean. Proceedings of an International Conference, University of Crete, Rethymno 2-5 June 2005 (Aegaeum 30). Liège and Austin: Université de Liège and University of Texas at Austin.

Younger, J. G. 2016a. Minoan women, pp. 573-94 in Budin, S. and MacIntosh Turfa, J. (eds.), Women in Antiquity: Real Women Across the Ancient World. London: Routledge.

Younger, J. G. 2016b. Identifying myth in Minoan art, pp. 433-8 in Alram-Stern, E., Blakolmer, F., Deger-Jalkotzy, S., Laffineur, R. and Weilhartner, J. (eds.), Metaphysis: Ritual, Myth and Symbolism in the Aegean Bronze Age. Proceedings of the 15th International Aegean Conference, Vienna, Institute for Oriental and European Archaeology, Aegean and Anatolia Department, Austrian Academy of Sciences and Institute of Classical Archaeology, University of Vienna, 22-25 April 2014 (Aegaeum 39). Liège: Peeters. 